\title{
GOVERNMENT RECOVERY OF INDEMNITY FROM NEGLIGENT EMPLOYEES: A NEW FEDERAL POLICY*
}

EMPLOYERS are liable for the torts of employees acting within the scope of their employment. ${ }^{1}$ But, having paid a judgment, an employer can maintain against the employee who committed the tort an indemnity action for the amount of the judgment. ${ }^{2}$ For various reasons, however, employers almost never bring such actions against their negligent workers. ${ }^{3}$

*Gilman v. United States, 206 F.2d 846 (9th Cir.), cert. granted, 74 Sup. Ct. 275 (1953).

1. E.g., Haskell v. Starbird, 152 Mass. 117, 142 N.E. 695 (1890); De Haen v. Rockwood Sprinkler Co., 258 N.Y. 350, 179 N.E. 764 (1932); Brown v. Southern Ry., 202 N.C. 256, 162 S.E. 613 (1932). See Harper, Torts 639 (1933); Prosser, Torts 473 (1941) ; Restatement, Agency \$219 (1933).

2. The indemnity action allows one vicariously liable for a tort to recover from the tortfeasor. E.g., cases cited in note 6 infra; Prosser, Torts 1114 (1941) ; Restatement, RESTITUTION $\$ 76$ (1937). It is entirely distinct from the contribution action which, where allowed, permits one joint tortfeasor to recover from his co-tortfeasor. E.g., United States v. Yellow Cab Co., 340 U.S. 543 (1951); Goldman v. Mitchell-Fletcher Co., 292 Pa. 354, 141 Atl. 231 (1928). See Restatenrent, Restitution $\$ 86$ (1937).

Employers can normally also recover the cost of defending the original action against them. Restatearent, Restitution $\$ 80$, comment $b, \$ 96$ (1937) : Restatement, JudGMENTS $\$ 107$, comment $i$ (1942). However, such additional recovery may be contingent upon the employer's having given his employee an opportunity to defend the original suit. See McCormick, Damages 250 (1935).

3. No especial difficulties inhere in the indemnity action itself. Possible reasons for the failure of employers to bring indemnity actions against their employees are: (1) the adverse effect on employee morale, (2) the inability of the employee to satisfy the judgment, and (3) the opposition of labor unions.

Research indicates only six reported cases in the Twentieth Century: Opper v. Tripp Lake Estates, Inc., 274 App. Div. 422, 84 N.Y.S.2d 461 (1948) (defendant summer camp sued by injured plaintiff impleaded its truck driver as a third party defendant for indemnity) ; Koontz v. Messer, 320 Pa. 487, 181 Atl. 792 (1935) (defendant oil company sued by injured plaintiff impleaded its salesman-driver for indemnity); State v. Yellow Baggage \& Transfer Co., 211 Wis. 391, 247 N.W. 310 (1933) (plaintiff moving company sued its driver and another employee for indemnity after paying a judgment to the state for damages to a bridge) ; Fedden v. Brooklyn Eastern District Terminal, 204 App. Div. 741, 199 N.Y. Supp. 9 (1923) (defendant company sued by injured plaintiff impleaded its negligent employee for indemnity) ; Gafiner v. Johnson, 39 Wash. 437, 81 Pac. 859 (1905) (owner of steamship having paid judgment for damages to another ship, sued his negligent ship master for indemnity); Costa v. Yoachim, 104 La. 170, 28 So. 992 (1900) (owner of wagon, after paying judgment for damages sustained in collision, sued his negligent driver).

Other Twentieth Century cases are commonly cited for the proposition that an employer may recover indemnity from his negligent employee. E.g., Washington Gas Light Co. v. District of Columbia, 161 U.S. 316 (1896) ; Scott v. Curtis, 195 N.Y. 424, 88 N.E. 794 (1909) : Rumpf v. Callo, 16 La. App. 12, 132 So. 763 (1931). Examination of these 
The Federal Government, on the other hand, has recently adopted the policy of claiming indemnity. ${ }^{*}$ In many instances it has recovered either by judgment or settlement." Despite one appellate holding denying the Government's asserted right to indemnity, ${ }^{\circ}$ Government claims against its employees continue.

The tort liability of the United States flows from the Federal Tort Claims Act, ${ }^{\text {s }}$ which waives the Gorernment's common law immunity from suit for the torts of its employees. ${ }^{9}$ Prior to the Act, claimants injured by Government workers could be compensated by the Government only after special congressional action. ${ }^{10}$ The Act was designed to relieve Congress of the burden of

cases reveals either that the party sued for indemnity was mot an employee or that the case does not involve indemnity at all and hence the proposition stated therein is dictum.

In two other recent cases employers have hruught actious against their negligent employees, for different purposes. In Buhl v. Viera, 328 Mass. 201, 102 N.E.2d 774 (1952), a druggist sued his negligent employee for the benefit of his insurance company which had paid damages to the person injured hy the employee's negligence. And in Darman v. Zilch, 56 R.I. 413, 186 Atl. 21 (1936), an automobile cwner sued his chauffeur for damage to his automobile caused by the chauffeur's negligence.

In only one case has a subrogated insurance company sued its insured's employee for damages it has had to pay on behalf of its insured because of the employee's negligence. Ohio Casualty Insurance Co. v. Capolino, 65 N.E.2d 287 (Ohio App. 1945).

4. Communication to the Yale Law Joursal frum Assistant Attorney-General (Civil Division) Warren E. Burger, dated October 27, 1953, in Yale Law Library.

5. E.g., United States v. Lushbough, 200 F.2d 717 (Sth Cir. 1952) ; Burks v. United States, Civil No. 6766, S.D. Tex, August 6, 1953; Darnell v. United States, Civil No. 9703-HW, S.D. Cal., January 15, 1952: Loumakis v. United States, Civil No. 43I, N.D. Ga., January 31, 1953.

6. Gilman v. United States, 2016 F.2d 846 (9th Cir. 1953). For discussion of this case, see text at note 27 infra.

7. See Pitcher v. United States, Civil No. 3896. D. Cum., June 16, 1953, presently on appeal, Civil No. 22854, before the United States Court of Appeals for the Secund Circuit. See also note 4 supra.

8. 28 U.S.C. $\$ 1346$ (b) (1946): "Subject to the provisions of Chapter 171 of this title, the district courts, together with the District Court for the Territory of Alasha, the United States District Court for the District of the Canal Zone and the District Court of the Virgin Islands, shall have exclusive jurisdiction of civil actions on claims against the United States, for money damages, accruing un and after January 1, 1945, for injury or loss of property, or personal injury or death caused by the negligent or wrongiul act or omission of any employee of the Government while acting within the scope of his office or employment, under circumstances where the United States, if a private person, would be liable to the claimant in accordance with the law of the place where the act or omission occurred."

9. Dalehite v. United States, 346 U.S. 15, 27-8 (1952): "The legislative history indicates that ... Congress desired to waive the Government's immunity from actions for injuries to persons and property occasioned by the tortious conduct of its agents asting within their scope of business. . . " See SeN. Rer. No. 1400, 79th Cong., 2d Sess. 29 (1946).

10. H.R. Rep. No. 2245, 77th Cong., 2d Sess. 5 (1942): "[C]linims, if adjusted at all, are handled individually by private bills, which either make a direct appropriation for the payment of the claim, or else remit the plaintiff to suit either in the Court of Claims or 
such private bills ${ }^{11}$ and to provide claimants with a judicial remedy against the United States. ${ }^{12}$

Prior to Government liability, the loss was borne by the injured victim unless he was covered by insurance, could recover from the negligent employee, or was compensated by private bill. Rarely was the victim fully protected by insurance. ${ }^{13}$ Usually the Government employee was financially unable to reimburse the injured party, ${ }^{14}$ and redress by private bill was not often forth. coming. ${ }^{15}$ Hence the Government's assumption of liability shifted pecuniary losses from injured parties to the Government.

in a United States district court." See United States v. Yellow Cab Co., 340 U.S. 543, 548-9 (1951). See also note 11. infra.

However, heads of executive agencies had authority to settle property claims up to $\$ 1000.42$ Stat. 1066 (1922), 31 U.S.C. $\$ 215$ (1946). And the heads of certain specified executive agencies also had authority to settle injury and death claims. E.g., 50 STAT. 321 (1937), 16 U.S.C. § 584-o (1946) (Civilian Conservation Corps); 41 STar. 1054 (1920), 33 U.S.C. $\$ 853$ (1946) (Coast and Geodetic Survey, subject to the approval of the Secretary of Commerce) ; 49 ST.ıT. 1184 (1936), 5 U.S.C. $\$ 300($ b) (Supp. 1950) (Department of Justice for the Federal Bureau of Investigation); 48 STAT. 1207 (1934), 5 U.S.C. $\$ 392$ (1946) (Post Office Department).

Today the heads of executive agencies are authorized to settle claims for property damage or personal injuries or death up to $\$ 1000$. 28 U.S.C. $\$ 2672$ (1946). And the Attorney-General has authority to compromise or settle any claim after a suit has been commenced. 28 U.S.C. $\$ 2677$ (1946).

11. Approximately 2000 private relief bills were introduced in each Congress during the 25 years prior to the Act and the amount claimed has exceeded $\$ 100,000,000$. However, only a small percentage of those bills ever became law. See Hearings beforc Judiciary Committec on H.R. 5373 and H.R. 6463, 77th Cong., 2d Sess. 25, Appendix 111 (1942) ; H.R. Rep. 1287, 79th Cong., 1st Sess. 2 (1946).

See also United States v. Yellow Cab Co., 340 U.S. 543, 549-50 (1951): "The bill became Title IV of the Legislative Reorganization Bill of 1946 at a moment when the overwhelming purpose of Congress was to make changes of procedure which would enable it to devote more time to major public issues." And see Dalehite v. United States, 346 U.S. 15, 24-5 (1952).

Title I of the Legislative Reorganization Act of 1946 banned private relief bills in cases where suit could be brought under the FTCA, 60 Star. 831. (1946).

12. Dalehite v. United States, 346 U.S. 15, $24-5$ (1952). See H.R. REP. No. 2245, 77th Cong., 2d Sess. 5 (1942) ; 3 Moore, Feneral Practice 513, n.14 (2d ed. 1948).

This statutory suit is a non-jury action. 28 U.S.C. $\$ 2402$ (1946).

13. See Health Insurance Council, Accident and Health Coverage in tine United States 7 (1952). As of December 31, 1951, nearly 86,000,000 people had insurance covering some hospital expenses-generally room, board, and miscellaneous services; $65,500,000$ people were covered for some medical expenses, commonly for in-hospital treatment and sometimes for home treatment also.

Approximately $40,000,000$ of the nation's $61,000,000$ employed civilians had insurance which would provide some income during periods in which injury or illness prevented them from working. Id. at 15 . In addition, various types of insurance are provided under federal and state government social security programs. Id. at 22.

14. See Hearings before Committee on the Judiciary on H.R. 5373 and H.R. 6463, 77th Cong., 2d Sess. 39 (1942). And few government employees carry liability insurance. See note 17 infra.

15. See first paragraph of note 11 supra. 
Sound policy requires that the Government bear the cost of losses resulting from the negligence of its employees. Since the Government originated the activity causing loss, and could have foreseen the probability of the loss, it should shoulder liability as an additional expense of the activity. Moreover, the Government can distribute the cost of liability through taration.1" Such distribution spreads the loss over a large number of people according to ability to pay. Each taxpayer pays only a small portion of the loss, thus avoiding the ruin which may be visited on an individual who is required to carry the entire burden of what is to him an unpredictable loss.17

Successful prosecution of Government indemnity claims, however, will shift the full loss back to an individual, the Government worker. Employees will be unable to distribute the loss except through insurance. However, employees are rarely insured against liability for negligent acts incident to their employment. $^{18}$ And to insist that Government workers bear the cost of insurance would place them in an economically disadvantageous position in comparison with private employees, who do not fear indemnity actions ${ }^{10}$ and do not insure against them. ${ }^{20}$ Private employers bear the cost of insurance as a busi-

16. See James, Accident Liability Reconsidered: The Impat of Liability Insuranec, 57 Yale L.J. 549, 556 (1948).

17. See James, Contribution Anong Joint Tortfasors, 54 Hanv. L. REv. 1156, 1157 (1941) :

"[Another] way of looking at tort liability is to regard it as a means for distributing losses over society as a whole or some fairly large segment of it. This approach leads to an altogether different set of conseguences. Most important among them is that some good accrues from the fact of distribution itself. It is true that the total cost of the direct loss-through accident, for eximplecannot be diminished by its distribution and indeed, is increased by the cost which the distribution itself entails. Social gain accrues, nevertheless, since consistent distribution of losses over a large group tends tu substitute (through the operation of the law of large numbers) a certain and calculable cust for the uncertain risk of ruinous losses to individuals. This removal of risk and uncertainty, moreover, eliminates fear inhibiting desirable enterprise, activity and progress. Finally, the protection of its members from financial ruin or great financial shock is a benefit to society as a whole quite apart from the gratification of humanitarian impulses."

See also James, Accident Liability Reconsidercd: The Impact of Liability Insturasec, 57 Yale L.J. 549, 549-50 (1948) ; Gregory, Contribution Among Joint Tortfcasors: A Defense, 54 Harv. L. Rev. 117, 171 (1941). See text at notes 13, 14 supro.

18. See Communication to the Yale Law Journal from J. J. Forman Co., Insurance Brokers, New York, dated December 10, 1953, in Yale Law Library. See also Ses. Rep. No. 2025, 82d Cong., 2d Sess. 2 (1952); Statement of Assistant Attorney-General Francis MI. Shea in Hearings before Committce on the Judiciary on H.R. 5373 and H.R. 6763, 77th Cong., 2d Sess. 29 (1942).

19. See note 3 supra.

20. See note is supra. There appear to be no insurance policies written to protect against indemnity itself. However, a policy against liability would cover an employee's liability on an indemnity action. 
ness expense ${ }^{21}$ and attempt to distribute it to the consumer through higher prices. $^{22}$

The indemnity action cannot be successfully defended as necessary to deter negligence. Liability is of questionable value as a negligence deterrent. ${ }^{2 a 3}$ And the Government has command of other disciplinary devices-including dismissal and demotion-with which to combat employee negligence. ${ }^{24}$ Moreover, modern methods of preventing negligence, proved effective, are available to the Government. ${ }^{25}$

Although fear that his employer may bring an indemnity action against him may deter an employee from colluding with an injured party, ${ }^{20}$ this possible deterrent effect is not a sufficient justification for the indemnity action. The law should not give the Government an action against all of its employees because some may be dishonest. Private employers have not found the danger of collusion sufficiently great to justify either bringing or threatening indemnity actions. ${ }^{27}$

21. See Communication to the Yale Law Jouksil from J. J. Forman Co, supra note 18. Some large concerns are self-insurers. See, c.g., Communication to the Yale: Law Journal from John A. Dill, General Attorney, Railway Express Agency, dated November 11, 1953, in Yale Law Library.

22. See Douglas, Vicarions Liability and Administration of Risk-I, 38 YALE L.J. 584, 586 (1929) ; Seavey, Speculations as to "Respondeat Superior" in Hakvard Leanl. EsSAYs 433, 450 (1934).

23. See James, Accident Liability Reconsidered: The Impact of Liability Instrance, 57 YAI.E L.J. 518 at 569 (1948). ( $f$. Note, 62 YALE L.J. 111, 115 (1952). Morcover. even if the government cannot collect indemnity the employee remains liable to the injured claimant, unless the claimant recovers from the government. See note 29 infra. But sce Seavey, Speculations as to "Respondeat Superior" in Harvard LeGaL Essays 433, 447 (1934).

24. Subject to specific procedural requirements. federal agencies have authority to dismiss, demote, suspend, and transfer civil service employees, and to reduce their compensation or withhold their promotion. 5 CoDE FED. ReGs. $\$ \S 8-9$ (1949); id. (Cum. Supp. 1952). Cf. Morris, The Torts of an Independent Contractor, 29 ILL. L. REv. 339, 341 (1934).

25. " $[\mathrm{T}]$ he large business or governmental unit is in a far better position to reduce accidents than is the isolated individual. . ." James \& Dickenson, Accident Pronchess and Accident Law, 63 HARv. L. Rev. 769, 780 (1950). This article suggests that psychological studies of the accident prone employee may be utilized to reduce accidents. Private employers have successfully used techniques developed from these studies.

See also McMurry, Handling Personalitty Adjustatents in Industry (1944), where it is suggested that psychological factors are of prime importance in employee efficiency and safety, and that employers may use psychological techniques in the selection, training, and educating of employees with great effect in eliminating negligence and inefficiency.

26. This fear was judicially expressed for the first time by Harrison, D.J., in Gilman v. United States, 206 F.2d 846, 850 (9th Cir. 1953) (dissenting opinion). See discussion of this case, text at note 28 infra.

27. See note 3 supra. 
In the recent case of Gilman 2 . Unitcd States, ${ }^{28}$ the Ninth Circuit denied indemnity to the Government, reasoning primarily from an inadequate explanation of the indemnity action. The court stated the rationale of indemnity thus: " the defendant is unjustly enriched by the plaintiff's payment of the injured party's claim." "29 Since the FTCA makes judgment in a suit against the Government a bar to any action by the claimant against the employee, the court concluded that the judgment extinguished the employee's liability to the injured party. 30 Hence the employee could not be enriched by the Government's payment of the judgment and was not subject to an indemnity action. But the court's theory of indemnity does not account for those cases which allow indemnity to the plaintiff despite the defendant's immunity from liability

28. Gilman v. United States, 206 F.2d 846 (9th Cir. 1953).

29. Id. at 847, quoting from Brief for Appellee, p. 7, Gilman v. United States, supra note 28 .

30. 28 U.S.C. $\$ 2676$ (1946) provides: "The judgment in an action under section 1346 (b) of this title shall constitute a complete bar to any action by the claimant, by reason of the same subiect matter, against the emplovee of the government whose act or omission gave rise to the claim."

This section alters the common law rule that a claimant may obtain judgment against all persons liable for the same tort. See Prosser, Torts 1106 (1941); Restatens:it, JUDGarexts $\$ 93$, comment $b$ (1942). At common law, only satisfaction of the judgment discharges those liable on the tort. See Prusser, Torts 1106 (1941); Restareuentir, JungMreNTs $\$ 95$ (1942). The innovation is justified by the assurance that a judgment against the government will be satisfied.

The section was designed to permit the government to continue its practice of defending suits instituted against its employees without risking the necessity of defending two suits. See Hearings before Committee on Judiciary on H.R. 5373 and H.R. 6463, 77th Cong., 2d Sess. 9-10 (1942). See also note 34 infra. Absent this provision, the Government might find itself defending claimant's suit against the negligent employee after it had defended claimant's suit against itself. If the claimant lost his statutory non-jury action against the Government he might then have proceeded against the employee, hoping to win the common law jury action. Or if the claimant won his suit against the Government, he might then have proceeded against the employee in the hope of receiving a larger jury: verdict. See Restatexient, Restitution $\$ 96$, comment $j$ (1942).

A literal construction of the section would preclude an action against the employce whenever any prior suit against the Government reaches judgment. This result is palpably unfair where judgment is rendered for the Government on the grounds that the employee acted outside the scope of his employment. See note 1 stpra. In such case the claimant is deprived of his remedy against the negligent employee merely because he mistakenly attempted to avail himself of his statutory remedy. Cf. United States v. Lushbough, $200 \mathrm{~F} 2 \mathrm{~d} 717$ (Sth $\mathrm{Cir}$. 1952). This result may be avoided by interpreting the vord "judgment" in the section as meaning judgment on the merits of the tort case.

Section 2676 does not prevent duplicate suits when the claimant brings action against the employee first. However, in such case a successful defense of the suit would bar subsequent proceedings against the Government. E.y., Prichard v. Nelson, 55 F. Supp. 506 (W.D. Va. 1942), aff'd, 137 F.2d 312 (4th Cir. 1943) ; Restatearent, Junguesits $\$ \S 96$, 99 (1942). If claimant won the suit against the emplosee and the judgment was not satisfied, the claimant may then proceed against the Government. However, the Government often satisfies judgments against its employees. See note 34 infra. 
on the obligation which the plaintiff paid. ${ }^{31}$ Since the defendant has not been enriched in these cases, the basis for indemnity cannot be unjust enrichment.

31. E.g., Koontz v. Messer, 320 Pa. 487, 181 Atl. 792 (1935) (indemnity granted to company which had paid judgment to employee's wife for negligent injury by employec despite employee's immunity from tort suit by his wife); Briggs v. Philadelphia, $316 \mathrm{~Pa}$. 48, 173 Atl. 316 (1934) (affirming lower court's award to city of indemnity from house owner whose negligent maintenance of sidewalk rendered city liable to plaintiff despite owner's immunity from tort suit from plaintiff, his minor child). Cf. Reed v. Humphrey, 69 Kan. 155, 76 Pac. 390 (1904) ; Boardman v. Paige, 11 N.H. 431 (1840); Haddens v. Chambers, 2 Dallas 236 (Pa. 1795). See also Schubert v. Schubert Wagon Co., 249 N.Y. 253, 164 N.E. 42 (1928), where Cardozo, J., speaking obiter, stated that indemnity would be allowed to an employer who paid a judgment for his employee's tort to the employec's wife despite the employee's immunity from tort suit by his wife. Compare Mclaurin v. McLaurin Furniture Co., 166 Miss. 180, 146 So. 877 (1933); Poulin v. Graham, 102 Vt. 307, 147 Atl. 698 (1929) (both cases allowing tort suits by wife against husband's cmployer despite husband's immunity from suit by wife and despite employer's admitted right to indemnity against husband), with Emerson v. Western Seed \& Irr. Co., 116 Neb. 180 , 216 N.W. 297 (1927) (disallowing tort suit by wife against husband's employer because husband was immune to tort suit by wife and because employer's right of indemnity would destroy immunity). See also Restatensent, Restitution $\$ \$ 76$, comment $b, 78$, comment $a, 86$; Restatement, JudgMents $\$ 96$, comment $g$ (1942).

Alternative theories for indemnity between employee and employer have been suggested. Cardozo, J., in Schubert v. Schubert Wagon Co., supra states that the basis for indemnity is the breach of the employee's duty to render faithful, non-negligent service to his employer. See also Mechem, Agevcy $\$$ 324, 333 (3d ed. 1923); Prosser, Torts 909 (1941); Restatement, Restitution, Coercion, Topic 3, p. 327 (1937); Tifrany, Agencr $\S \S 142-5$ (2d ed., Powell, 1924). Another suggested basis for indemnity is that each person is responsible for the consequences of his own tort. Dunn v. Uvalde Asphalt Paving Co., 175 N.Y. 214, 67 N.E. 439 (1903). Accord: Oceanic S.N. Co. v. Compania Transatlantica, 134 N.Y. 461, 31 N.E. 987 (2d Div. 1892).

32. Furthermore, the court's reasoning is faulty in that it relies on an assumption that the court specifically declines to make. That assumption is that the right to indemnity does not arise on judgment but arises only on satisfaction of the judgment. If the contrary is assumed, then, by the court's theory, the Government's claim of indemnity becomes theoretically the same as the private employer's claim. The private employer is allowed indemnity because his payment to claimant discharges his employee's liability and thus unjustly enriches the employee. If the right to indemnity arises on judgment, then the Government would be entitled to indemnity because judgment which statutorily discharges the employee's liability to claimant, unjustly enriches the employee. However, if the right to indemnity arises only on payment, then the court's theory is consistent. For then, the Government's payment to the injured party would not enrich the employee, whose liability was discharged by the judgment, and would not give rise to indemnity. However, although this assumption is crucial to the court's conclusion, the court explicitly declines to make the assumption, Gilman v. United States, 206 F.2d 846, $848 \mathrm{n} .2$ (1953), and does not criticize the lower court for awarding indemnity to the Government on judgment and before payment.

For the proposition that indemnity can arise only on payment, see Dum v. Uvalcle Asphalt Paving Co., 175 N.Y. 214, 67 N.E. 439 (1903) ; Oceanic S.N. Co. v. Compania Transatlantica, 134 N.Y. 461, 31 N.E. 987 (2d Div. 1892). For the statement that indemnity can arise on liability and before payment, see L.B. Laboratories, Inc. v. Mitchell, 237 P.2d 84 (Cal. App. 1952). 
A better ground for denying indemnity to the Government is that it runs counter to the congressional intent embodied in the FTCA. This intent is evident from the legislative history of the Act:33 it is shown also by Congress' continuing practice of reimbursing by private bill those Government workers who have been sued instead of the Government. ${ }^{31}$ Mloreover, when Congress paid plaintiffs by private bill prior to the FTCA, the Government could not recover indemnity from its employees. ${ }^{35}$ If Congress had intended to grant the Government a right against its workers in the Act which created

33. See Hearings before Committee on Indiciary on H.R. 5373 and H.R. G663, 77 th Cong., 2d Sess. 10 (1942) :

"The Chairman. What is the arrangement when the government has an emplayce who is guilty of gross negligence and injury results? Is there any requirement that that employee should in any way respond to the Government if it has to pay for the injury, in the event of gross negligence?

"[Assistant Attorney General Francis M.] Shea. Not if he is a Government employce. Under those circumstances, the remedy is to fire the employee.

"Mr. McLaughin. No right of subrogation is set up?

"Mr. Shea. Not against the employee."

See also SEN. Rep. No. 1196, 77th Cong., 2d Sess. 5 (1942) : "It is just and desirable that the burden of redressing wrongs of this character be assumed by the Government alone, within limits leaving the employee at fault to be dealt with under the usual disciplinary controls."

The 77th Congress had under consideration an earlier edition of the oft-proposed Federal Tort Claims Act which was passed by the 79th Congress in 1946. Although the Supreme Court in United States v. Yellow Cab Co., 340 U.S. 543, 550 n.S (1951), questioned the force of the 1942 legislative history in the interpretation of the 1946 Act, the Court in Dalehite v. United States, 346 U.S. 15, 26 (1953), indicated that, concerning issues on which the 79th Congress held no relevant hearings, the hearings and reports of the 77th Congress must control un the question of legislative intent.

Cf. Opinion of Attorney General Robert H. Jackson, 40 Ops. ATr'Y Ges. 38, 40 (1941) : "... Congress has by general legislation progressively assumed liability to persons sustaining injuries through negligence of officers and employees of the Government and in doing so has not made provisions for the assertion of claims by the United States against the officers and employees causing the damage." See, however, SEx. REP. No. 2025, 82d Cong., 2d Sess. 2 (1952), which indicates a belief that the Government has a right to indemnity from its negligent employees. However, this subsequent expression of the $22 \mathrm{~d}$ Congress, made after the Government instituted its policy of claiming inderanity and before indemnity was denied by the Ninth Circuit, does not state the legislative intent of the 79th Congress, which passed the Federal Tort Claims Act.

34. See, e.g., 66 Stat. Al43 (1952). See also Sen. Rep. No. 2025, $82 d$ Cong., $2 d$ Sess. 2 (1952), citing legislative precedent for this type of private bill.

The Government sometimes pays the judgments rendered against its employees for torts arising in their employment. See Sex. Rep. Nos. 2025, 2043, 82d Cong., 2d Sess. (1952).

And the Department of Justice often defended negligent government employees when tort suits were brought against them. See Statement of Assistant Attorney General Francis M. Shea in Hearings before Committee on the Jtddiciary on H.R. 5373 and H.R. 6463,77 th Cong., 2d Sess. 9 (1942).

35. Since private bills were voluntary payments by the Government, no right of in- 
Governmental liability for its employees' torts, it would have made its intention explicit..36

Government indemnity is an issue for the sole determination of Congress..$^{17}$ In view of clear congressional intent to omit the right of indemnity from the FTCA, and indemnity's patently injurious effects, the current administrative policy of attempting to recover indemnity from Government employees should be discontinued. Economy does not demand so much. ${ }^{38}$

demnity arose. Liability of the payor is an element of his indemnity cause of action. Restatement, Restitution $\$ \$ 78$, comments $d, g ; 79$ (1937).

The payee's judgment against the payor binds the person from whom the payor seeks indemnity on the liability question if the payor offered him the opportunity to defend the payee's suit against the payor. Restatement, Junginents $\$ 107$ (1942).

The payor need not wait until judgment for the payee is entered against him in order to be entitled to indemnity. If he pays before judgment, however, he must be able to prove his liability to the payee in order to collect indemnity. Dunn v. Uvalde Asphalt Paving Co., 175 N.Y. 214,67 N.E. 439 (1903).

Some cases hold that even if the payor pays the payee in response to a judgment, the payor in order to collect indemnity must "allege and prove that judgment could not have been avoided." E.g., Keljikian v. Star Brewing Co., 303 Mass. 53, 54, 20 N.E.21 465, 466-7 (1939).

36. See note 37 infra. But see dissenting opinion of Harrison, D.J., in Gilman v. United States, 206 F.2d 846 (9th Cir. 1953), where the view is expressed that if Congress had meant to withhold this ordinary incident of vicarious liability, it would have clearly stated so. However, this opinion rests heavily on the analogy of the private employer, which the Supreme Court has stated should not be applied to the Government. See note 37 infra. Moreover, Congress was doubtless aware of the fact that private employers do not pursue such claims. See note 3 supra.

37. United States v. Standard Oil Co. of California, 332 U.S. 301 (1947). In this case the Government sought to recover for loss of services and for medical expenses necessitated by injuries to a soldier caused by defendant's negligence. The Court denied the Government's claim, declaring that common law precedents regarding indemnity may not be applied to the Government to judicially create a liability which Congress by silence declined to create. The Court held indemnity was a matter of fiscal policy for the sole determination of Congress.

38. Indeed, economy may not be served at all. If the Government's policy is to sue for indemnity in all cases, it is not likely that recoveries will meet expenses. And if the policy involves investigation of financial worth in each case, expenses are likewise liable to exceed recoveries. 